\title{
EGFR wt Allele
}

National Cancer Institute

\section{Source}

National Cancer Institute. EGFR wt Allele. NCI Thesaurus. Code C51744.

Human EGFR wild-type allele is located within 7p12 and is approximately $188 \mathrm{~kb}$ in length.

This allele, which encodes epidermal growth factor receptor protein, is involved in several different processes such as receptor signaling, differentiation, proliferation responses and signal transduction. 